\title{
PENERAPAN ILMU KOMUNIKASI DAN PSIKOLOGI \\ DALAM PROSES DAKWAH PENGARUHNYA TERHADAP \\ PENGAMALAN AGAMA MASYARAKAT \\ DI KECAMATAN PADANGSIDIMPUAN SELATAN
}

\author{
HAMLAN \\ Lecturer of Da'wa and Communications Faculty at IAIN Padangsidimpuan. \\ Street T. Rizal Nurdin Km. 4.5 Sihitang Padangsidimpuan 22733 \\ Email: hamlan.iain@gmail.com
}

\begin{abstract}
This research aimed to know the influence of implementing the communications and psychology itself in process of da'wa or both (communications and psyschology) to the religious practice of society. The sample of this research is 120 persons chosen by cluster sampling. Data have been collecting through questionnaires; then analyzed by using statistical and descriptive statistical analysis of inferential. From data analysis, it is known that the implementation of communications has strong influences to the religious practice of society, it is 0.929. It also happens to the implementation of psychology, it is also found that the influence is strong, it is 0.880. From two varibales (implementation of communications and implementation of psychology), it has strong influences to the religious practice of society, it is about 0.939 . It can be said that the influence of the implementation of communication to the religious practice of society in Padangsidimpuan Selatan disctrict is positif and significant. It is proved by the result, that is $27.339>1.659$. Then, the implementation of psychology to the religious practice of society is also positif and significant, it is $20.114>$ 1.659. Finally, both variables (communications and psychology) give positif and significant influence to the religious practice of society, it is $437.897>$ 3.08 .
\end{abstract}

Keywords:

Implementation, communications, psychology, and the religious practice.

\begin{abstract}
Abstrak
Penelitian ini bertujuan untuk mengetahui berapa besar pengaruh penerapan ilmu komunikasi dan psikologi dalam proses dakwah baik secara tersendiri maupun secara simultan (bersama-sama) terhadap pengamalan agama masyarakat. Sebanyak 120 orang masyarakat yang dijadikan sebagai sampel dengan menggunakan teknik Cluster Sampling. Pengumpulan data dilakukan melalui kuesioner (angket). Selanjutnya data yang terkumpul dianalisis dengan menggunakan analisis statistik deskriptif dan statistik inferensial. Dari hasil analisis tersebut diketahui bahwa penerapan ilmu komunikasi pengaruhnya sangat kuat terhadap pengamalan agama yaitu 0.929. Begitu juga dengan penerapan psikologi pengaruhnya sangat kuat terhadap pengamalan agama yaitu 0,880, selanjutnya dilihat dari kedua
\end{abstract}


variabel tersebut secara simultan berpengaruh kuat terhadap pengamalan agama sebesar 0,939. Dari analisis data diperoleh hasil penerapan ilmu komunikasi berpengaruh positif dan signifikan terhadap pengamalan agama masyarakat di Kecamatan Padangsidimpuan Selatan yaitu 27,339 > 1,659. Begitu pula penerapan psikologi berpengaruh positif dan signifikan terhadap pengamalan agama yaitu 20,114 > 1,659. Selanjutnya secara simultan kedua variabel tersebut pengaruh positif dan signifikan terhadap pengamalan agama yaitu 437,897 >3, 08 .

Kata Kunci: penerapan, ilmu komunikasi, psikologi, pengamalan agama.

\section{PENDAHULUAN}

Secara esensi dakwah adalah proses transformasi, implementasi dan membahasakan suara Tuhan (kalam Allah) kepada makhluk-Nya, agar dimengerti, dipahami dan dilaksanakan mengenai segala sesuatu yang menyangkut hubungan manusia dengan Tuhannya, manusia dengan sesamanya dan manusia dengan alam.

Sebagaimana dikemukakan Ahmad Ghulusy dikutip oleh M. Munir, “Dakwah adalah pekerjaan atau ucapan untuk mempengaruhi manusia mengikuti Islam" ${ }^{1}{ }^{1}$ Dengan demikian fokus pemikiran dakwah ialah memberi pengertian kepada umat manusia agar mengamalkan ajaran Allah yang terkandung di dalam al-Qur'an sebagai jalan hidupnya.

Mentransfer dan membahasakan bahasa Tuhan yang terdapat dalam al-Qur'an membutuhkan berbagai ilmu yang dapat diterapkan agar tugas-tugas tersebut dapat dijalankan dengan baik. Di antara ilmu dimaksud adalah ilmu komunikasi. Komunikasi memang merupakan suatu hal yang sangat fundamental dalam kehidupan manusia, bahkan di tengah suasana masyarakat dimana persaingan makin ketat, kehidupan semakin penuh dengan pilihan-pilihan (sebagai akibat dari demokratisasi) dan meningkatnya kecenderungan permisif dan hedonisme (sebagai akibat dari interdependensi pasar dan materialisme global), semakin banyaknya paradoks kehidupan dan sulitnya memegang monopoli kebenaran serta berkembang suburnya aliran-aliran/ajaran yang menyesatkan umat Islam.

Berbagai argumentasi tersebut memberi pengertian bahwa manusia adalah makhluk yang senantiasa membutuhkan bimbingan Ilahi (dakwah) yang dapat dikomunikasikan dengan baik, agar manusia dapat menempuh jalan yang benar di dalam hidup dan kehidupannya. Untuk menyampaikan risalah secara keseluruhan, sistematis dan mendalam tidak dapat dilakukan oleh setiap orang. Dalam hal ini diperlukan orang-orang yang memiliki pengetahuan yang mendalam tentang agama, dan seperangkat pengetahuan tentang bagaimana mengkomunikasikan risalah tersebut agar memperoleh hasil yang maksimal. Sebagaimana firman Allah:

\footnotetext{
${ }^{1}$ M. Munir, Metode Dakwah (Jakarta: Prenada Media, 2003), h. 153.
} 


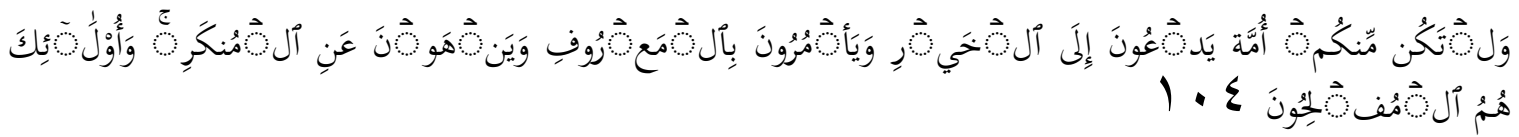

"Dan hendaklah ada di antara kamu segolongan umat yang menyeru kepada kebajikan, menyuruh kepada yang makruf dan mencegah dari yang mungkar, dan mereka itulah orang-orang yang beruntung". ${ }^{2}$

Ayat di atas mengingatkan kepada umat manusia agar di antara umat tersebut ada yang berupaya merubah tingkah laku/perbuatan yang tidak sesuai dengan ajaran Ilahi. Upaya ini dapat dilakukan melalui penyampaian beberapa pesan dengan cara memberi penjelasanpenjelasan yang memungkinkan orang lain atau komunikan dapat mengikutinya dengan sadar tanpa paksaan.

Suatu kenyataan bahwa menghadapi medan perjuangan dakwah dalam rangka menegakkan ajaran Ilahi di muka bumi ini tidak selamanya berjalan mulus. Secara normatif, masyarakat Islam adalah masyarakat unggulan, yakni khairu ummah, karena memiliki petunjuk alQur'an dan syari'ah Islam yang sempurna. Akan tetapi, dalam realitas saat ini umat Islam belum mencerminkan sifat-sifat keunggulan tersebut. Di Padangsidimpuan, contohnya umat Islam merupakan mayoritas dalam kuantitas tetapi masih minoritas dalam kualitas.

Fenomena ini sekaligus mempertanyakan efektifitas dakwah selama ini yang dilakukan para da'i/muballigh. Harus diakui bahwa umumnya kegiatan dakwah lebih banyak dilakukan secara improvisasi, tanpa konsep, tanpa perencanaan dan tidak pernah secara sungguh-sungguh dilakukan evaluasi. Akibatnya, berbagai kegiatan dakwah yang dilakukan kehilangan relevansinya dengan tantangan dan kebutuhan umat. Hal ini diduga disebabkan sebahagian para da'i/muballigh belum menerapkan berbagai ilmu yang terkait dengan proses dakwah di antaranya ilmu komunikasi dan psikologi.

Komunikasi dan psikologi merupakan ujung tombak bagi keberhasilan pelaksanaan dakwah di tengah masyarakat. Sebab audiens atau khalayak yang menerima pesan dakwah terdiri dari berbagai macam karakter, pemikiran, sikap, pemahaman, tingkat pendidikan, sosial budaya, ekonomi serta orientasi keagamaannya. Dengan adanya heterogenitas latar belakang anggota masyarakat, seorang da'i/muballigh perlu membahasakan atau mengkomunikasikan dakwah secara baik serta mengenal kejiwaan para audiensnya, sehingga pesan-pesan dakwah dapat diterima dengan baik pula. ${ }^{3}$

Berdasarkan pemikiran di atas, peneliti merasa perlu melakukan penelitian tentang pelaksanaan dakwah yang berlangsung di tengah-tengah masyarakat, tepatnya di

2 Yayasan Penyelenggara Penterjemah al-Quran, al-Quran dan Terjemahnya (Semarang: Toha Putra, 1989), h. 93.

\footnotetext{
${ }^{3}$ Toto Tasmara, Komunikasi Dakwah (Jakarta:Gaya Media Pratama,1997), h. 49-56
} 
Kecamatan Padangsidimpuan Selatan. Daerah ini menjadi perhatian peneliti karena berbagai pertimbangan di antaranya banyak majlis taklim, kegiatan pengajian di Mesjid, kegiatan menafsir al-Qur'an dan kegiatan dakwah lainnya. Namun jika dilihat dari pengamalan agama dan pengaktualan nilai-nilai Ilahiah pada diri umat Islam yang ada di Kecamatan ini belum sebanding dengan maraknya kegiatan dakwah yang dilaksanakan di masyarakat tersebut.

Peneliti berasumsi bahwa setiap kegiatan yang dilaksanakan tidak sesuai dengan hasil yang diperoleh, berarti ada hal-hal yang kurang efektif. Demikian pula halnya dengan kegiatan dakwah yang dilaksanakan di Kecamatan Padangsidimpuan Selatan diduga masih kurang efektif dan belum menyentuh kejiwaan masyarakat bila ditinjau dari sudut pandang ilmu komunikasi dan psikologi. Fenomena inilah yang mendorong peneliti untuk menganalisis lebih dalam problema dakwah dimaksud dengan mengangkat judul: "Penerapan Ilmu Komunikasi dan Psikologi dalam Proses Dakwah Pengaruhnya Terhadap Pengamalan Agama Masyarakat di Kecamatan Padangsidimpuan Selatan".

Berdasarkan pembatasan masalah seperti disebutkan di atas, maka masalah penelitian ini dirumuskan sebagai berikut:

a. Berapa besar pengaruh penerapan ilmu komunikasi dalam proses dakwah terhadap pengamalan agama masyarakat di Kecamatan Padangsidimpuan Selatan?

b. Berapa besar pengaruh penerapan psikologi dalam proses dakwah terhadap pengamalan agama masyarakat di Kecamatan Padangsidimpuan Selatan?

c. Berapa besar pengaruh penerapan ilmu komunikasi dan psikologi secara simultan dalam proses dakwah terhadap pengamalan agama masyarakat di Kecamatan Padangsidimpuan Selatan?

Adapun tujuan yang ingin dicapai dalam penelitian ini adalah untuk:

a. Mengetahui berapa besar pengaruh penerapan ilmu komunikasi dalam proses dakwah terhadap pengamalan agama masyarakat di Kecamatan Padangsidimpuan Selatan

b. Mengetahui berapa besar pengaruh penerapan psikologi dalam proses dakwah terhadap pengamalan agama masyarakat di Kecamatan Padangsidimpuan Selatan

c. Menjelaskan besarnya pengaruh penerapan ilmu komunikasi dan psikologi secara simultan dalam proses dakwah terhadap pengamalan agama masyarakat di Kecamatan Padangsidimpuan Selatan.

Berbicara tentang ilmu komunikasi, menurut Carl I. Hovland sebagaimana dikutip Onong Uchjana, ilmu komunikasi adalah "Upaya yang sistematis untuk merumuskan secara tegas asas-asas penyampaian informasi serta pembentukan pendapat dan sikap". ${ }^{4}$

h. 10 .

4 Onong Uchjana Effendy, Ilmu Komunikasi Teori Dan Praktek (Bandung: Remaja Rosdakarya, 2001), 
Dalam tulisan ini yang dijadikan teori pendukung adalah apa yang dikemukakan Harold Lasswell yang dikutip oleh Effendy, beliau menyatakan bahwa cara yang terbaik untuk menjelaskan kegiatan komunikasi ialah dengan menjawab pertanyaan "Who Says What In Which Channel To Whom With What Effect " 5

Dari teori tersebut, jelas bahwa orang yang menyampaikan pesan, yaitu komunikator ikut menentukan berhasil tidaknya komunikasi. Dalam hubungan ini faktor source credibility komunikator memegang peranan yang sangat penting. Istilah kredibilitas ini adalah istilah yang menunjukkan nilai terpadu dari keahlian dan etos pada dirinya, yakni good sense, good moral, and good character. Kemudian diformulasikan oleh para cendekiawan modern menjadi i'tikat baik (good intentions), kelayakan untuk dipercaya (trustworthiness) sera kecakapan atau keahlian (competence or expertness). ${ }^{6}$ Seorang komunikator akan berhasil mengubah sikap, opini serta perilaku komunikan jika dalam dirinya terdapat sejumlah kredibilitas yang ditawarkan para ahli tersebut.

Pengaruh/efek adalah salah satu elemen dalam komunikasi yang sangat penting untuk mengetahui berhasil tidaknya komunikasi yang diinginkan. Pengaruh dapat dikatakan mengena jika perubahan yang terjadi pada penerima sama dengan tujuan yang diinginkan oleh komunikator. Seperti rumus yang dibuat oleh Jamias, yaitu pengaruh sangat ditentukan oleh sumber, pesan, media dan penerima. ${ }^{7}$

Untuk mencapai tujuan komunikasi secara efektif, seorang komunikator perlu memahami sifat-sifat komunikasi dan pesan guna dapat menentukan jenis media yang akan diambil dan teknik komunikasi yang akan ditetapkan. Teknik persuasif sering dikatakan sebagai kegiatan psikologis, hal ini dikarenakan teknik ini menggunakan manipulasi psikologis sehingga komunikan bertindak atas kehendaknya sendiri.

Menurut psikologi Islami manusia merupakan makhluk satu wujud tiga aspek dan dua dimensi. Yang dimaksud tiga aspek tersebut adalah aspek jismiah, aspek nafsiah dan aspek ruhaniah. Sementara keenam dimensi tersebut yaitu al-jism, al-nafsu, al-aql, al-qalb, alruh dan al-fitrah. ${ }^{8}$

Sebenarnya pada diri manusia terdapat suatu insting atau naluri yang disebut religius insting, yaitu naluri untuk meyakini dan mengadakan penyembahan terhadap suatu kekuatan di luar diri manusia. Naluri inilah yang mendorong manusia untuk mengadakan kegiatan keagamaan. Namun pada kenyataannya manusia dihadapkan pada berbagai gempuran modernisasi, sehingga sebahagian dari mereka tampak kehilangan arah (disorientasi), kehilangan keseimbangan dan keselarasan (disharmoni), bahkan putus harapan (hopeless). Akibatnya kekuatan iman yang selama ini dimiliki setiap hari mengalami

\footnotetext{
5 Onong Uchjana Effendy, Dinamika Komunikasi (Bandung: Remaja Rosdakarya, 2000), h. 29.

6 Effendy, Ilmu Komunikasi Teori Dan Praktek, h. 34.

${ }^{7}$ Hafied Cangara, Pengantar Ilmu Komunikasi (Jakarta: Raja Grafindo Persada, 2004), h. 147.

${ }^{8}$ Baharuddin, Paradigma Psikologi Islami (Yogyakarta: Pustaka Pelajar, 2004), h. 230.
} 
degradasi. Untuk mengisi kekosongan spiritual ini dibutuhkan dakwah/siraman rohani yang dapat mengembalikan serta mencerdaskan spiritualitas umat.

Bertitik tolak dari kerangka teori dan kerangka berpikir, maka hipotesis penelitian ini adalah:

a. Terdapat pengaruh positif yang signifikan penerapan ilmu komunikasi dalam proses dakwah terhadap pengamalan agama masyarakat di Kecamatan Padangsidimpuan Selatan.

b. Terdapat pengaruh positif yang signifikan penerapan psikologi dalam proses dakwah terhadap pengamalan agama masyarakat di Kecamatan Padangsidimpuan Selatan.

c. Terdapat pengaruh positif yang signifikan penerapan ilmu komunikasi dan psikologi secara simultan dalam proses dakwah terhadap pengamalan agama masyarakat di Kecamatan Padangsidimpuan Selatan.

\section{METODOLOGI PENELITIAN}

Populasi penelitian ini adalah seluruh masyarakat yang beragama Islam, berusia 35 55 tahun, bertempat tinggal di kecamatan Padangsidimpuan Selatan yang tersebar di 12 kelurahan, berjumlah 4.798 orang. Namun karena kemampuan peneliti yang sangat terbatas, maka secara acak sederhana hanya diambil 4 kelurahan. Keempat kelurahan tersebut dipandang sudah dapat mewakili ciri-ciri masyarakat di Kecamatan Padangsidimpuan Selatan.

Kemudian dari keempat kelurahan ini masing-masing diambil 30 orang sebagai sampel dengan cara cluster yaitu berdasarkan usia, jenis kelamin, latar belakang pendidikan agama, pekerjaan dan kegiatan dakwah/keagamaan yang diikuti. Dengan demikian diperoleh sampel penelitian sebanyak 120 orang sampel.

Dalam penelitian ini alat (instrumen) pengumpul data yang digunakan adalah: Kuesioner. Kuesioner ini digunakan untuk mengukur variabel bebas dan variabel terikat. Variabel bebas dalam penelitian ini yaitu penerapan ilmu komunikasi dalam proses dakwah yang dilambangkan dengan variabel $X$. Sedangkan variabel terikat penelitian ini adalah pengamalan agama yang dilambangkan dengan variabel Y. Untuk mengukur variabelvariabel tersebut digunakan skala likert ${ }^{9}$ dengan kata-kata Sangat Sering (SS), Sering (S), Kadang-kadang (K), Hampir Tidak Pernah (HTP), Tidak Pernah (TP) atau yang sejenisnya.

Data dianalisis dengan meggunakan program Statistical Package for Social Sciences (SPSS) for windows versi 11,5 secara kuantitatif dalam bentuk analisis statistik deskriftif dan analisis statistik inferensial. Kemudian data kuantitatif tersebut diinterpretasikan dan dianalisis dan kemudian diambil kesimpulan.

\footnotetext{
${ }^{9}$ Skala likert adalah alat ukur mengenai sikap, pendapat dan persepsi seseorang atau kelompok orang tentang gejala sosial. Lihat Syukur Kholil, Metodologi Penelitian Komunikasi (Bandung: Citapustaka Media, 2006), h. 144.
} 


\section{HASIL PENELITIAN DAN PEMBAHASAN}

\section{Pengujian Hipotesis}

Penelitian ini mempunyai 3 (tiga) buah hipotesis yang akan diuji. Untuk menguji hipotesis pertama dan kedua dilakukan analisis regresi sederhana antara variabel bebas dengan variabel terikat yaitu antara X1 dengan Y dan X2 dengan Y. Sedangkan untuk menguji hipotesis ketiga digunakan rumus regresi ganda. Lebih lengkapnya dapat dilihat pada pembahasan berikut ini.

a. Terdapat Pengaruh Positif yang Signifikan Penerapan Ilmu Komunikasi Dalam Proses Dakwah Terhadap Pengamalan Agama Masyarakat di Kecamatan Padangsidimpuan Selatan

Tabel 1

Model Summary(b)

\begin{tabular}{|c|r|r|r|r|}
\hline Model & $\mathrm{R}$ & R Square & \multicolumn{1}{|c|}{$\begin{array}{c}\text { Adjusted R } \\
\text { Square }\end{array}$} & $\begin{array}{c}\text { Std. Error of the } \\
\text { Estimate }\end{array}$ \\
\hline 1 & $.929(\mathrm{a})$ & .864 & .862 & 3.67277 \\
\hline
\end{tabular}

a Predictors: (Constant), PENERAPAN ILMU KOMUNIKASI

b Dependent Variable: PENGAMALAN AGAMA

Tabel 2

Hasil Ringkasan Anova Untuk Uji Signifikansi X1 Terhadap Y

\begin{tabular}{|r|r|r|r|r|r|r|}
\hline \multicolumn{2}{|c|}{$\begin{array}{l}\text { Mol } \\
\text { del }\end{array}$} & \multicolumn{1}{c|}{$\begin{array}{l}\text { Sum of } \\
\text { Squares }\end{array}$} & df & $\begin{array}{l}\text { Mean } \\
\text { Square }\end{array}$ & F & \multicolumn{1}{c|}{ Sig. } \\
\hline 1 & Regression & 10082.238 & 1 & 10082.238 & 747.42 & $.000(\mathrm{a})$ \\
& Residual & 1591.729 & 118 & 13.489 & & \\
& Total & 11673.967 & 119 & & \\
\hline
\end{tabular}

a Predictors: (Constant), PENERAPAN ILMU KOMUNIKASI

b Dependent Variable: PENGAMALAN AGAMA

Tabel 3

Hasil Analisis Regresi Sederhana X1 Terhadap Y

\begin{tabular}{|c|c|c|c|c|c|c|}
\hline \multirow{2}{*}{$\begin{array}{c}\text { Mod } \\
\text { el }\end{array}$} & & \multicolumn{2}{|c|}{$\begin{array}{c}\text { Unstandardized } \\
\text { Coefficients }\end{array}$} & \multirow{2}{*}{$\begin{array}{c}\text { Standardized } \\
\text { Coefficients } \\
\text { Beta } \\
\end{array}$} & \multirow[t]{2}{*}{$\mathrm{t}$} & \multirow[t]{2}{*}{ Sig. } \\
\hline & & B & Std. Error & & & \\
\hline 1 & $\begin{array}{l}\text { (Constant) } \\
\text { PENERAPAN } \\
\text { ILMU } \\
\text { KOMUNIKASI }\end{array}$ & $\begin{array}{r}6.775 \\
.969\end{array}$ & $\begin{array}{r}2.157 \\
.035\end{array}$ & .929 & $\begin{array}{r}3.142 \\
27.339\end{array}$ & $\begin{array}{l}.002 \\
.000\end{array}$ \\
\hline
\end{tabular}

a Dependent Variable: PENGAMALAN AGAMA 
Berdasarkan tabel 1 bahwa besarnya pengaruh antara variabel penerapan ilmu komunikasi dengan pengamalan agama diperoleh koefisien korelasi (r) sebesar 0,929. Hal ini menunjukkan pengaruh yang kuat di antara penerapan ilmu komunikasi dalam proses dakwah terhadap pengamalan agama.

Berdasarkan analisis tabel 1 terdapat $\mathrm{R}$ square atau koefisien determinasi sebesar 0,864 yang merupakan hasil pengkuadratan dari koefisien korelasi (r) 0,929 atau 0,9292. Ini berarti variabel penerapan ilmu komunikasi memberi pengaruh sebesar 86,40\% $\left(\mathrm{r}^{2} \mathrm{x}\right.$ $100 \%$ atau $\left.0,929^{2} \times 100 \%\right)$ terhadap pengamalan agama. Sedangkan sisanya 13,60\% dapat disebabkan oleh faktor-faktor lain.

Dari tabel 3 menggambarkan bahwa persamaan regresi sebagai berikut:

$\mathrm{Y}=\mathrm{a}+\mathrm{b} 1 \mathrm{X} 1=6,775+0,929 \mathrm{X} 1$

Dimana:

$\mathrm{X} 1$ = Penerapan ilmu komunikasi dalam proses dakwah

$\mathrm{Y}=$ Pengamalan agama

Konstanta sebesar 6,775 menyatakan bahwa jika tidak ada kenaikan nilai dari variabel Penerapan ilmu komunikasi dalam proses dakwah (X1), maka nilai Pengamalan agama (Y) adalah 6,775. Koefisien regresi sebesar 0,929 menyatakan bahwa setiap penambahan (karena ada tanda + ) satu skor atau nilai penerapan ilmu komunikasi dalam proses dakwah akan memberikan peningkatan skor sebesar 0,929.

Terlihat bahwa pada kolom sig (signifikan) pada tabel 3 terdapat nilai 0,002 atau probabilitas jauh dibawah 0,05. Karena nilai $\mathrm{t}$ hitung $>$ nilai $\mathrm{t}$ tabel atau 27,339 >1,659 dan $\mathrm{F}$ hitung $>$ nilai $\mathrm{F}$ tabel atau 747,43 > 3,08 maka hipotesis diterima artinya penerapan ilmu komunikasi dalam proses dakwah berpengaruh secara signifikan terhadap pengamalan agama.

b. Terdapat Pengaruh Positif yang Signifikan Penerapan Psikologi Dalam Proses Dakwah Terhadap Pengamalan Agama Masyarakat di Kecamatan Padangsidimpuan Selatan

Tabel 4

Model Summary(b)

\begin{tabular}{|l|r|r|r|r|}
\hline Model & $\mathrm{R}$ & R Square & $\begin{array}{c}\text { Adjusted R } \\
\text { Square }\end{array}$ & $\begin{array}{c}\text { Std. Error of the } \\
\text { Estimate }\end{array}$ \\
\hline 1 & $.880(\mathrm{a})$ & .774 & .772 & 4.72641 \\
\hline
\end{tabular}

a Predictors: (Constant), PENERAPAN PSIKOLOGI

b Dependent Variable: PENGAMALAN AGAMA 
Tabel 5

Hasil Ringkasan Anova Untuk Uji Signifikansi X2 Terhadap Y

\begin{tabular}{|r|l|r|r|r|r|r|}
\hline Model & & $\begin{array}{c}\text { Sum of } \\
\text { Squares }\end{array}$ & df & Mean Square & F & Sig. \\
\hline 1 & Regression & 9037.966 & 1 & 9037.966 & 404.583 & $.000(\mathrm{a})$ \\
& Residual & 2636.001 & 118 & 22.339 & & \\
& Total & 11673.967 & 119 & & & \\
\hline
\end{tabular}

a Predictors: (Constant), PENERAPAN PSIKOLOGI

b Dependent Variable: PENGAMALAN AGAMA

Tabel 6

Hasil Analisis Regresi Sederhana X2 Terhadap Y

\begin{tabular}{|r|r|r|r|r|r|r|}
\hline Model & & \multicolumn{2}{|c|}{$\begin{array}{c}\text { Unstandardized } \\
\text { Coefficients }\end{array}$} & $\begin{array}{c}\text { Standardized } \\
\text { Coefficients }\end{array}$ & $\mathrm{t}$ & \multicolumn{1}{c|}{ Sig. } \\
\hline & & \multicolumn{1}{|c|}{$\mathrm{B}$} & Std. Error & Beta & & \\
\hline 1 & (Constant) & 9.881 & 2.775 & & 3.561 & .001 \\
PENERAPAN & .880 & .044 & .880 & 20.114 & .000 \\
PSIKOLOGI & & & & & & \\
\hline
\end{tabular}

a Dependent Variable: PENGAMALAN AGAMA

Berdasarkan tabel 4 bahwa besarnya pengaruh antara variabel penerapan psikologi dengan pengamalan agama diperoleh koefisien korelasi (r) sebesar 0,880. Hal ini menunjukkan pengaruh yang kuat di antara penerapan psikologi dalam proses dakwah terhadap pengamalan agama.

Berdasarkan analisis tabel 4 terdapat $\mathrm{R}$ square atau koefisien determinasi sebesar 0,774 yang merupakan hasil pengkuadratan dari koefisien korelasi (r) 0,880 atau $0,880^{2}$. Ini berarti variabel penerapan psikologi memberi pengaruh sebesar 77,40 \% ( $r^{2} \times 100 \%$ atau $\left.0,880^{2} \times 100 \%\right)$ terhadap pengamalan agama. Sedangkan sisanya $22,60 \%$ dapat disebabkan oleh faktor-faktor lain.

Dari tabel 6 menggambarkan bahwa persamaan regresi sebagai berikut:

$\mathrm{Y}=\mathrm{a}+\mathrm{b} 2 \mathrm{X} 2=9,881+0,880 \mathrm{X} 2$

Dimana:

$\mathrm{X} 2$ = Penerapan psikologi dalam proses dakwah

$\mathrm{Y}=$ Pengamalan agama

Konstanta sebesar 9,881 menyatakan bahwa jika tidak ada kenaikan nilai dari variabel Penerapan psikologi dalam proses dakwah (X2), maka nilai Pengamalan agama (Y) adalah 9,881. Koefisien regresi sebesar 0,880 menyatakan bahwa setiap penambahan 
$($ karena ada tanda + ) satu skor atau nilai penerapan psikologi dalam proses dakwah akan memberikan peningkatan skor sebesar 0,880.

Terlihat bahwa pada kolom sig (signifikan) pada tabel 16 terdapat nilai 0,001 atau probabilitas jauh dibawah 0,05. Karena nilai $t$ hitung $>$ nilai $t$ tabel atau 20,114 > 1,659 dan F hitung > nilai $\mathrm{F}$ tabel atau 404,58 > 3,08 maka hipotesis diterima artinya penerapan psikologi dalam proses dakwah berpengaruh secara signifikan terhadap pengamalan agama.

c. Terdapat Pengaruh Positif yang Signifikan Penerapan Ilmu Komunikasi dan Penerapan Psikologi Secara Simultan Dalam Proses Dakwah Terhadap Pengamalan Agama Masyarakat di Kecamatan Padangsidimpuan Selatan

Tabel 7

Hasil Korelasi X1 dan X2 Terhadap Y

\begin{tabular}{|l|r|r|r|c|}
\hline Model & $\mathrm{R}$ & R Square & $\begin{array}{c}\text { Adjusted R } \\
\text { Square }\end{array}$ & $\begin{array}{c}\text { Std. Error of the } \\
\text { Estimate }\end{array}$ \\
\hline 1 & $.939(\mathrm{a})$ & .882 & .880 & 3.42910 \\
\hline
\end{tabular}

a Predictors: (Constant), PENERAPAN ILMU KOMUNIKASI, PENERAPAN PSIKOLOGI

b Dependent Variable: PENGAMALAN AGAMA

Tabel 8

Hasil Ringkasan Anova Untuk Uji Signifikansi X1 dan X2 Terhadap Y

\begin{tabular}{|c|c|c|c|c|c|c|}
\hline Model & & $\begin{array}{c}\text { Sum of } \\
\text { Squares }\end{array}$ & $\mathrm{df}$ & $\begin{array}{l}\text { Mean } \\
\text { Square }\end{array}$ & $\mathrm{F}$ & Sig. \\
\hline 1 & $\begin{array}{l}\text { Regression } \\
\text { Residual } \\
\text { Total }\end{array}$ & $\begin{array}{r}10298.197 \\
1375.769 \\
11673.967\end{array}$ & $\begin{array}{r}2 \\
117 \\
119\end{array}$ & $\begin{array}{r}5149.099 \\
11.759\end{array}$ & 437.897 & $.000(a)$ \\
\hline
\end{tabular}

a Predictors: (Constant), PENERAPAN ILMU KOMUNIKASI, PENERAPAN PSIKOLOGI

b Dependent Variable: PENGAMALAN AGAMA

Tabel 9

Hasil Analisis Regresi Ganda X1 dan X2 Terhadap Y

\begin{tabular}{|c|c|c|c|c|c|c|}
\hline \multirow[t]{2}{*}{ Model } & & \multicolumn{2}{|c|}{$\begin{array}{c}\text { Unstandardized } \\
\text { Coefficients }\end{array}$} & \multirow{2}{*}{$\begin{array}{c}\text { Standardized } \\
\text { Coefficients } \\
\text { Beta }\end{array}$} & \multirow[t]{2}{*}{$\mathrm{t}$} & \multirow[t]{2}{*}{ Sig. } \\
\hline & & B & $\begin{array}{l}\text { Std. } \\
\text { Error }\end{array}$ & & & \\
\hline 1 & $\begin{array}{l}\text { (Constant) } \\
\text { PENERAPAN } \\
\text { ILMU } \\
\text { KOMUNIKASI } \\
\text { PENERAPAN } \\
\text { PSIKOLOGI }\end{array}$ & $\begin{array}{r}4.589 \\
.711\end{array}$ & $\begin{array}{r}2.077 \\
.069\end{array}$ & .682 & $\begin{array}{r}2.209 \\
10.353\end{array}$ & $\begin{array}{l}.029 \\
.000\end{array}$ \\
\hline
\end{tabular}

a Dependent Variable: PENGAMALAN AGAMA 
Berdasarkan tabel 7 bahwa besarnya pengaruh antara variabel penerapan ilmu komunikasi dan penerapan psikologi dengan pengamalan agama diperoleh koefisien korelasi (r) sebesar 0,939. Hal ini menunjukkan pengaruh yang kuat penerapan ilmu komunikasi dan psikologi secara simultan dalam proses dakwah terhadap pengamalan agama.

Berdasarkan analisis tabel 7 terdapat $\mathrm{R}$ square atau koefisien determinasi sebesar 0,882 yang merupakan hasil pengkuadratan dari koefisien korelasi (r) 0,939 atau 0,9392. Ini berarti variabel penerapan ilmu komunikasi dan penerapan psikologi memberi pengaruh sebesar $88,20 \%\left(\mathrm{r}^{2} \times 100 \%\right.$ atau $\left.0,939^{2} \times 100 \%\right)$ terhadap pengamalan agama. Sedangkan sisanya $11,80 \%$ dapat disebabkan oleh faktor-faktor lain.

Dari tabel 19 menggambarkan bahwa persamaan regresi sebagai berikut:

$$
\mathrm{Y}=\mathrm{a}+\mathrm{b} 1 \mathrm{X} 1+\mathrm{b} 2 \mathrm{X} 2=4,589+0,682 \mathrm{X} 1+0,282 \mathrm{X} 2
$$

Konstanta sebesar 4,589 menyatakan bahwa jika tidak ada kenaikan nilai dari variabel penerapan ilmu komunikasi dan penerapan psikologi secara simultan dalam proses dakwah (X1 dan X2), maka nilai Pengamalan agama (Y) adalah 4,589. Koefisien regresi sebesar 0,682 dan 0,282 menyatakan bahwa setiap penambahan (karena ada tanda + ) satu skor atau nilai penerapan ilmu komunikasi dan penerapan psikologi secara simultan dalam proses dakwah akan memberikan peningkatan skor sebesar 0,682 dan 0,282 .

Dari hasil analisis tabel 18 nilai F hitung diperoleh sebesar 437,897 sedangkan nilai $\mathrm{F}$ tabel sebesar 3,08 atau 437,897 > 3,08, maka hipotesis diterima artinya terdapat pengaruh yang signifikan penerapan ilmu komunikasi dan penerapan psikologi secara simultan dalam proses dakwah terhadap pengamalan agama masyarakat di Kecamatan Padangsidimpuan Selatan.

\section{Pembahasan}

Berdasarkan hasil penelitian ini dapat diketahui bahwa penerapan ilmu komunikasi dan psikologi oleh da'i dalam proses dakwah masih dalam katergori cukup. Demikian pula dengan pengamalan agama mayarakat masih tergolong sedang. Hal ini menunjukkan bahwa para da'i ketika akan melaksanakan kegiatan dakwah belum menerapkan berbagai ilmu yang terkait dengan dakwah tersebut. Pelaksanaannya masih secara tradisional saja. Kebanyakan da'i terjun ke dunia dakwah lebih merupakan panggilan ibadah dibanding sebagai keharusan yang didasari analisis ilmiah.

Seharusnya masyarakat mau mendengarkan, menerima dan menghayati, mengikuti serta mengamalkan ajaran-ajaran Islam dengan penuh kesadaran, akan tetapi dikarenakan faktor da'i yang menyampaikan ajaran agama tersebut kurang kharismatik, bahasanya tidak menarik serta penyampaiannya bersifat monolog, maka perhatian masyarakat tidak sepenuhnya dicurahkan kepada materi atau pesan dakwah tersebut. 
Dalam mengembangkan potensi beragama ini peran para da'i sangat menentukan. Ketika da'i berbicara terjadi proses menangkap stimuli. Stimulus itu dipersepsi oleh pendengar, kemudian diubah menjadi informasi selanjutnya disimpan dalam memorinya. Jika dakwah yang disampaikannya menarik, mereka kemudian akan meresponnya dengan berpikir dan pikiran itulah yang akan menuntun pendengar tersebut untuk merespon dakwah dengan perbuatan/pengamalan atau sebaliknya tidak perlu merespon. Hal ini sejalan dengan makna dakwah yang dikemukakan Tutty Alawiyah ${ }^{10}$ yaitu sebagai proses transaksional artinya hanya dakwah yang berharga yang akan dibeli orang.

Penyampaian ajaran agama bersifat monolog, dengan memandang suatu persoalan secara hitam putih tanpa argumen yang kuat yang disemangati oleh Kalam Allah dan Sunnah Rasul, sehingga terkesan menggurui, jenuh dan membosankan. Jarangnya para da'i mengajak untuk berpikir dan menyentuh kalbu, serta menumbuhkembangkan potensi psikhis pendengarnya. Hal ini menyebabkan ceramah agama tidak mendapat tempat di hati masyarakat, membuat kualitas pengamalan agama mereka tidak meningkat Oleh karena itu selayaknya seorang da'i dalam melaksanakan dakwahnya menerapkan ilmu komunikasi dan pendekatan psikologi Islam.

\section{KESIMPULAN}

Dari hasil penelitian ini dapat ditarik beberapa kesimpulan sebagai berikut:

1. Penerapan ilmu komunikasi dalam proses dakwah berpengaruh secara signifikan terhadap pengamalan agama.

Besarnya pengaruh variabel penerapan ilmu komunikasi terhadap pengamalan agama adalah 0,929 sedangkan kontribusi variabel X1 terhadap Y sebesar 86,40\% kemudian sisanya 13,60 \% ditentukan oleh variabel lain. Pengaruhnya sangat signifikan karena nilai t hitung > nilai t tabel atau 27,339 >1,659, dan nilai F hitung $>$ nilai $F$ tabel yaitu 747,43 > 3,08 .

2. Penerapan psikologi dalam proses dakwah berpengaruh secara signifikan terhadap pengamalan agama.

Besarnya pengaruh variabel penerapan psikologi dalam proses dakwah terhadap pengamalan agama adalah 0,880 sedangkan kontribusi variabel X1 terhadap $\mathrm{Y}$ sebesar $77,40 \%$ kemudian sisanya $22,60 \%$ ditentukan oleh variabel lain. Pengaruhnya juga sangat signifikan karena nilai thitung $>$ nilai $\mathrm{t}$ tabel atau 20,114 >1,659 dan nilai $\mathrm{F}$ hitung $>$ nilai F tabel yaitu $404,58>3,08$.

3. Penerapan ilmu komunikasi dan psikologi secara simultan dalam proses dakwah berpengaruh secara signifikan terhadap pengamalan agama.

10 Tutty Alawiyah A.S., "Paradigma Baru Dakwah Islam; Pemberdayaan Sosio-Kultural Mad'u," dalam Dakwah, Vol. 3. No.2 November 2001, h. 9. 
Besarnya pengaruh Penerapan ilmu komunikasi (X1) dan psikologi (X2) secara simultan dalam proses dakwah terhadap pengamalan agama (Y) tergolong kuat yaitu sebesar 0,939. Sedangkan kontribusi secara bersama-sama (simultan) variabel X1 dan $\mathrm{X} 2$ terhadap Y adalah $88,20 \%$ sedangkan sisanya 11,80\% ditentukan oleh variabel lain. Penerapan ilmu komunikasi dan psikologi secara simultan dalam proses dakwah berpengaruh secara signifikan terhadap pengamalan agama dibuktikan dengan diperoleh nilai $\mathrm{F}$ hitung > nilai F tabel yaitu 437,897 >3,08. 


\section{DAFTAR RUJUKAN}

A. S, Tutty Alawiyah. "Paradigma Baru Dakwah Islam; Pemberdayaan Sosio-Kultural Mad'u," dalam Dakwah, Vol. 3. No.2 November 2001.

Baharuddin, Paradigma Psikologi Islami. Yogyakarta: Pustaka Pelajar, 2004.

Cangara,Hafied. Pengantar Ilmu Komunikasi. Jakarta: Raja Grafindo Persada, 2004.

Effendy,Onong Uchjana. Ilmu Komunikasi Teori Dan Praktek. Bandung: Remaja Rosdakarya, 2001.

Dinamika Komunikasi. Bandung: Remaja Rosdakarya, 2000.

Kholil, Syukur. Metodologi Penelitian Komunikasi. Bandung: Citapustaka Media, 2006.

Munir, M. Metode Dakwah. Jakarta: Prenada Media, 2003.

Tasmara,Toto. Komunikasi Dakwah. Jakarta:Gaya Media Pratama,1997.

Yayasan Penyelenggara Penterjemah al-Quran. al-Quran dan Terjemahnya. Semarang: Toha Putra, 1989. 